\title{
Translation Approaches in Constitutional Hermeneutics
}

\author{
Hans Lind ${ }^{1}\left(\mathbb{D} \cdot\right.$ Christina Mulligan $^{2}$ (D) $\cdot$ Michael Douma $^{3}$ (D) $\cdot$ Brian Quinn $^{4}$ (ID
}

Published online: 21 May 2020

(c) The Author(s) 2020

\begin{abstract}
In this article, we suggest an alternate approach to interpreting the US Constitution, using founding-era translations. We demonstrate how both symmetries and asymmetries in structure and vocabulary of the languages involved can help in deciding nowadays' problems of constitutional interpretation. We select seven controversial passages of the US constitution to illustrate our approach: Art. I, § 8, cl. 3 ("to regulate commerce"); Art. II, $\S 1$, cl. 5 ("natural born citizen"); Art. II, $\S 2$, cl. 3 ("recess"); Art. I, § 6, cl. 1/Art. I, § 8, cl. 10/Art. IV, § 2 ("felony"); and Art. IV, § 2, cl. 1 ("privileges and immunities"). Since these passages have recently been debated by constitutional scholars, reassessing them using our method can establish the additional value of our approach to constitutional practice. We presume that our approach is not limited to interpreting the US constitution, but suggest that constitutional hermeneutics in general could profit from adding a translation approach to the toolkit.
\end{abstract}

Keywords Constitution · Interpretation · German · Dutch · Translation · Originalism

\section{Introduction}

The United States Constitution was translated into German and Dutch for the Germanand Dutch-speaking populations of Pennsylvania and New York shortly before its ratification. ${ }^{1}$ Although copies of both the German- and Dutch-language Constitutions

\footnotetext{
${ }^{1}$ The primary translations this article will refer to are: Verfahren der Vereinigten Convention gehalten zu Philadelphia, In dem Jahr1787, Und dem Zwölften Jahr der Americanischen Unabhängigkeit. Auf Verordnung der General Assembly von Pennsylvanien aus dem Englischen übersetzt [71]; and De Constitutie, eenpariglyk geaccordeerd by de Algemeene Conventie, gehouden in de Stad von Philadelphia, in

Hans Lind

hans.lind@aya.yale.edu

1 Universität Konstanz, Fach 157, Universitätsstrasse 10, 78457 Konstanz, Germany

2 Brooklyn Law School, 250 Joralemon Street, Brooklyn, NY 11201, USA

3 The Georgetown Institute for the Study of Markets and Ethics, Georgetown University, PO Box 48, Bloomery, WV 26817, USA

4 New York, NY 10036, USA
} 
have been preserved and are reprinted in a German collection of constitutions edited by Horst Dippel [19], they have largely escaped analysis until now. This article presents and analyzes translations of the United States Constitution with a view to making several modest but significant contributions to the field of constitutional interpretation.

The article examines the text of the translations and explains how they can clarify the meaning of the Constituion's original text. The translations provide evidence of the Constitution's original public meaning - the meaning of the text as understood by its contemporary translators and as reflected in their interpretive choices. The translations also provide examples of situations where there were multiple "original public meanings" - where members of the public developed different interpretations of the same text. More generally, this essay proposes that translations constitute a uniquely advantageous source of constitutional commentary by virtue of their ability to comprehensively and contextually analyze the Constitution's text. Unlike other sources, such as published pamphlets, the ratifiers' speeches, or contemporary dictionaries, the translated constitutions exhaustively restate every term and phrase in the Constitution and represent those terms and phrases in context.

\section{Original Public Meaning and the Hermeneutics of Constitutional Translation}

In 1786, the commissioners of a constitutional convention held in Annapolis recommended a convention in Philadelphia [35, p. 109]. The latter convention adjourned after completing the drafting of the Federal Constitution. Shortly after the convention adjourned, Pennsylvania's congressional delegation requested a meeting with the Pennsylvania general assembly, the state's legislative body [39, p. 59]. Benjamin Franklin hoped that by quickly ratifying the Constitution, Pennsylvania could secure the location of the new nation's capital [39, p. 59]. On September 24 and 25,1787 , the Pennsylvania assembly ordered the printing of 3000 copies of the Constitution in English and 1,500 copies of the Constitution in German "to be distributed throughout th[e] state for the inhabitants thereof" [33, pp. 62-64]. ${ }^{2}$ At the time, around $1 / 3$ of the population of Pennsylvania primarily spoke German [49, p.

\footnotetext{
Footnote 1 (continued)

't Jaar 1787: en gesubmitteerd aan het Volk der Vereenigde Staaten van Noord-Amerika, Vertaald door Lambertus de Ronde, Gedruckt by Order van de Federal Committee, in de Stad van Albany [72]. The German translation of the Constitution used here is a Michael Billmeyer print. According to [19, p. 64 n.61], it is not identical to "the first two German translations" which appeared in the Gemeinnützige Philadelphische Correspondenz on September 25, 1787, or to a translation in Neue Unpartheyische Lancäster Zeitung, printed on September 26, 1787. However, the Billmeyer text was commissioned by the Pennsylvania General Assembly, was distributed among the German-speaking population of Pennsylvania, and is identical to three contemporary editions of the translation by Matthias Börtgis in 1787, Charles Webster in 1788, and Melchior Steiner in 1788.

2 On September 24, Assemblyman William Findlay moved that three-thousand copies be printed in English and five-hundred printed in German [39, p. 62]. Later in the day it appears Findlay moved for onethousand copies to be printed in English and five-hundred copies in German, and the motion "was agreed to" [39, p. 63]. The following day, "[Assemblyman] Robert Whitehall[,] thinking the number, ordered [the previous day] to be published of the plan of the federal government, [was] too small ... moved to add two thousand more to that motion" [39, p. 63]. Assemblyman Hugh Brackenridge disagreed, arguing
} 
310], ${ }^{3}$ and the relative number of constitutions printed in each language reflected this proportion. Assemblymen William Will of Philadelphia, Adam Hubley of Lancaster County, and Philip Kreemer of Berks County were appointed to a committee to "engage a proper person to translate the plan [Constitution] into the German language" [33, pp. 57, 63]. The assembly's German language printing was undertaken by Michael Billmeyer [33, p. 64]. However, the translator's name does not appear on the Billmeyer copies [35] and does not appear to be known. The Dutch translation, rendered by a minister, Lambertus De Ronde, was produced separately at the bequest of a pro-Constitution faction. In the late 1700s, the Dutch language was still spoken widely in New York, specifically in the rural areas around New York City "west of the Hudson, in New Jersey, around Kingston, and along the upper reaches of the Hudson and the Mohawk" [66, p. 34]. The Dutch translation was printed in 1788 to gather support for New York's ratification, "by Order van de [of the] Federal Committee" [19, p. 80], a group which explicitly advocated ratification of the Federal Constitution in New York [39, p. 328]. The printer of the Dutch translation, Charles Webster, owner of the Albany Gazette and Albany Journal, is notable for having printed pamphlets by both the Anti-Federal and Federal Committees [39, pp. 333-334]. ${ }^{4}$

Principally, the translations provide evidence of the Constitution's original public meaning - the meaning of the text as understood by its contemporary translators and as reflected in their interpretive choices. With "Originalism" currently being the method of constitutional interpretation embraced by many judges, such as Justice Thomas and Justice Gorsuch, our texts should to be considered as indispensable tools in the endeavor of constitutional hermeneutics.

Especially New Originalists can profit from a founding-era translation approach. "New Originalism" or "Original Meaning Originalism" is a bundle of theories of constitutional interpretation that share the common conviction that not the framers' original intent, but the constitution's original public meaning is the relevant hermeneutical criterion [cf. 73]. While some understand the ratifier of the constitution as the relevant public, "original public meaning" is usually defined as "the meaning

Footnote 2 (continued)

that, "the number of fifteen hundred, ordered yesterday, would be enough to convey the information generally through the state" [39, p. 63]. It was eventually ordered that "two thousand copies in English and one thousand in German be printed in addition" [39, p. 64]. Adding the totals from September 24 and September 25, it would appear that, three-thousand copies were printed in English and fifteen-hundred were printed in German. Describing these events, Pauline Maier wrote, "On Tuesday, September 25, the assembly ordered two thousand copies of the Constitution printed in English and another thousand in German for distribution throughout the state" [39, p. 60]. However, Maier did not mention the September 24 order.

3 According to the 1790 Census, 160,000 of Pennsylvania's 434,373 inhabitants were German, and "German was the standard language in the area where the German population was concentrated" [54, p. 310]. See also [18], explaining that most authorities agree that German speakers in Pennsylvania constituted about one-third of the total population of Pennsylvania between 1730 and 1790 .

4 On April 10, 1788, Webster printed a circular by the Anti-Federal Committee raising over thirty objections to the Constitution; about ten days later he published the Federal Committee's nearly point-by-point rebuttal [44, p. 328]. 
that the words would have had to a reasonably well-informed speaker or reader of the English language at or about the time the text was adopted" [48, p. 253]. According to Lawrence Solum, this "linguistic meaning" of the Constitution " is a function of (1) the [original] conventional semantic meanings of the words and phrases that make up the text and (2) the [original] rules of syntax and grammar that combine the words and phrases" [58, p. 10]. To reconstruct such "conventional semantic meaning" [58, p. 14], scholars do not need to consult the usual sources [as, e.g., "the records of the Constitutional Convention, the ratification debates, and the Federalist Papers" 5, p. 101], but can excavate the common linguistic practice(s) of use by resorting to founding-era dictionaries, records, non-legal books, or even newspapers.

This article proposes that founding-era translations of the US Constitution constitute a uniquely advantageous source of constitutional commentary by virtue of their ability to comprehensively and contextually analyze the Constitution's text. Unlike other sources, the translated constitutions exhaustively restate every term and phrase in the Constitution and represent those terms and phrases in context. But one might question whether translations are really the kinds of sources which can illuminate original meaning. Part of the reason we generally consult the works of prominent late eighteenth-century commentators to understand the Constitution is "because they reflect the considered analyses of intelligent observers far closer to the relevant events [of the founding] than we are today" [40, p. 1356]. ${ }^{5}$ De Ronde and the German translator were similarly-situated, intelligent members of the late eighteenthcentury American polity, but one might question whether their translations represent "considered analyses" such as those printed in a pamphlet or articulated in a speech.

For their translations to possess the exegetical value associated with contemporary commentary and debate, their work would need likewise to have an analytical component, or more precisely, for their thought process to include an analytic step. On this point, there is virtually unanimous consensus among linguists and translation scholars: no substantive epistemological difference exists between a commentary and a translation. Translation entails, and always has entailed, a process of analysis. Although this claim is intuitive, establishing it is not trivial. The competing possibility - that translation is some rote process, where word $A$ in the source language becomes word $A^{\prime}$ in the target - comes readily to mind. But on the contrary, analysis and commentary is a necessary part of translation, where the "representation of hidden significance through an embryonic attempt at making it visible is of so singular a nature that it is rarely met with in the sphere of nonlinguistic life" $[8$, p. 17].

Even the earliest canonical mention of translation in the Western tradition-Cicero's account of adapting Greek drama into his native Latin—describes the translator

\footnotetext{
5 In other words, "these works are simply good constitutional commentary by members who were or nearly were members of the political community within which the Constitution was adopted" [38, p. 1178]. To the extent that the original understanding of the ratifiers is considered significant, the translations are additionally relevant to those questions, as there is a good chance that some ratifiers in Pennsylvania and New York had seen the translations. Notably, the chairman of the Pennsylvania ratifying convention, Frederick Augustus Muhlenberg, was the son of a German Lutheran pastor and had studied in Germany for many years [see 59, pp. 84-85, 202].
} 
digesting the source language and expressing it, as he saw fit, in the target language [51]. Consider an example of translation from Roman Jakobson, the most prominent member of the Russian Formalist School of linguistics. In Jakobson's example, a writer is trying to translate the English sentence "She has brothers" (not, it will be noted, a grammatically complex concept in English) into another language, such as Arabic, that recognizes not only a singular and a plural, but also a dual form $[32$, p. 114]. Does the writer here use the plural form, knowing that this denotes at least three brothers, or the dual, which limits the total to two? Or perhaps it may be more desirable to write around the problem, translating the sentence less than literally ("She has more than one brother"), or else express the idea in Arabic with great precision but little grace ("She has two or more than two brothers")?

Whichever option the writer chooses, the translation of even this simple sentence necessarily becomes an interpretive act, with a variety of possible consequences. In one case, the translator may make an error-such as by using the plural form when the dual would have been correct. In another, there may not be a fact of the matter about how many brothers the woman has, and the translator may choose to create a more precise meaning an author did not intend.

In yet another case, the translator may know from another source how many brothers the woman has, and correctly add this fact in the translation, supplementing a reader's substantive understanding of a situation.

In many other cases, the analytic act will not be so obvious. In the vast majority of cases, in fact, it is trivial. As Jakobson puts it, "[1]anguages differ essentially in what they must convey and not in what they may convey" [32, p. 116]. Arabic must convey a distinction between two and more than two, while English may but is not required to. However, many expressions in English and Arabic are exactly alike in what they must convey.

The translation of any number of common concepts, attributes, and relations may be essentially verbatim. Crucially, though, this does not mean that a translation is a simple word-to-word or phrase-to-phrase match. To determine that concepts are equivalent in two languages and can be verbatim-translated is, itself, a cognitive or analytic step. To recognize areas where analysis is required means recognizing the ones where it is not. Synthesizing three centuries of European philosophy, from Schleiermacher and Hegel to Heidegger, George Steiner advanced a theory of translation that described it as the "hermeneutic motion"- the very name of which describes translation as a process of analysis (hermeneutics) that precedes bringing a text into another language (the motion) [61]. ${ }^{6}$

Indeed, even in one of the most rigorous and precise of all hermeneutic traditions-Talmudic scholarship — it is assumed that "every translation is always a commentary" [45, p. 45]. De Ronde's and the unknown German's translations constitute,

\footnotetext{
6 Similarly, Lawrence Lessig has noted, "The translator's task is always to determine how to change one text into another text, while preserving the original text's meaning. And by thinking of the problem faced by the originalist as a problem of translation, translation may teach something about what a practice of interpretive fidelity might be" [see 33, p. 1173].
} 
therefore, commentaries or "considered analyses" - an additional source to access the original public meaning of the Constitution as translated in the late 1780s.

The German and Dutch translations of the Constitution are not merely $a$ source to aid constitutional interpretation; they are also a new kind of source, one that possesses the unique quality of being both contextual and comprehensive. The translations are contextual because each translated term is understood in relation to the rest of the clause and document in which it appears, rather than in isolation. They are comprehensive because they restate each and every term and phrase in the Constitution, rather than just those of interest [7, p. 107]. ${ }^{7}$

In contrast, consider the other types of textual sources that one might look to in order to discover the Constitution's meaning to the founding-era public. Vasan Kesavan and Michael Stokes Paulsen enumerate, "(1) the public (and sometimes private) writings of the Federalists and Anti-Federalists; (2) the public debates of the state ratifying conventions; (3) the early congressional, executive, and judicial interpretations of the Constitution; (4) the works of early commentators on the Constitution; and ... (5) the secret drafting history of the Constitution" [34, pp. 1125-1126]. Consulting commentary such as these for perspective on the constitutional text's meaning is a part of the constitutional interpreter's toolkit [see 11, p. 7, 25, pp. 1195-1199].

But these sources all present one notable limitation: rarely, if ever, does any single analysis purports to exhaustively treat an entire text-the entirety of the Constitution-in a consistent level of detail [34, pp. 1125-1126]. As a result, the work of any one commentator, while explicating the meaning of a certain section of text, does not always situate it comparatively with respect to all other relevant parts of the text. In short, commentaries on the Constitution's text are contextual-they analyze the text in context-but are rarely if ever truly comprehensive [3, p. 748]. ${ }^{8}$

By contrast, the one common source that provides a potentially comprehensive reference for all possible terms - a contemporary dictionary-applies to the language in general, but not to the specific constitutional context [34, p. 1202]. Here, further work must be done to determine which of several dictionary definitions, if any, is an appropriate explanation of a term as used in the Constitution or whether a term had acquired some specialized or technical meaning [38, p. 373]. ${ }^{9}$

\footnotetext{
7 "[U]nlike ordinary readers, [translators] are not allowed to skip."

8 "By viewing the document's clauses in splendid isolation from each other-by reducing a single text to a jumble of disconnected clauses - readers may miss the significance of larger patterns of meaning at work."

9 Maggs describes several of the challenges of using a dictionary to resolve the meaning of a term in the Constitution: "First, the definition might come from the wrong kind of dictionary. A definition from an English language dictionary may be inapplicable to a constitutional term that has a specialized legal meaning, and, vice versa, a definition from a legal dictionary may be inapplicable to a constitutional term used in a non-specialized way. Second, even if the proper kind of dictionary is consulted, if the dictionary contains multiple definitions for the same word, some of these meanings ascribed to the word may
} 
In short, the translated Constitutions boast a unique advantage that is not shared by other sources: they exhaustively restate every term and phrase in the Constitution and represent those terms and phrases in context. Unlike published pamphlets, the ratifiers' speeches, or contemporary dictionaries, these translations are both contextual and comprehensive.

As such, the translated Constitutions may be not only valuable but uniquely valuable to at least certain investigations into original public meaning. ${ }^{10}$ As sources, they are hardly perfect. For instance, as our project revealed, the translations occasionally contain clear mistakes - in addition to potentially other more subtle errors - that obscure the translator's actual understanding [38, p. 379]. ${ }^{11}$ Moreover, discovering a slippage of meaning in the translation of the English to the Dutch or German versions is just half the battle; a researcher would need to analyze the public meaning of the Dutch or German terms of interest as well, requiring specialized knowledge and research. One would also need to posit the degree to which a difference in meaning was a choice made based on the translator's understanding of the English text, or a choice based on other values such as style or brevity at the expense of precision.

Despite these challenges, the existence of multiple language translations of the Constitution has the potential to clarify rather than muddy the document's meaning. In a related context, Lawrence Solan has argued that the European Union's practice of referencing multiple, equally-authentic translations of European legislation actually can increase confidence in the texts' meanings [56, pp. 294-300]. ${ }^{12}$ "Sometimes a particular translation has captured [a point], but at other times, reading the various translations suggests a common theme, expressed in different words by each translator. ... The ability to compare different versions and then to triangulate ... brings out nuances that can help the investigator to gain additional insight into the thoughts of the original drafter" [56, pp. 292-293]. The same potential to "triangulate" is present here. The early German and Dutch translations of the Constitution in fact speak to numerous constitutional debates, as the following five examples will substantiate.

Since the linguistic particularities we use are not limited to the three languages that were relevant for our project, our approach can be well used in order to

\footnotetext{
Footnote 9 (continued)

not apply to the word as it is used in the particular context of the Constitution. Third, dictionary definitions do not always capture the correct meaning of words that form a part of a phrase or compound, such as "Vice President" or "declare war"” [43, p. 373].

10 The translations may be particularly helpful for producing intratextualist interpretations of the Constitution. Intratextual interpretation involves "the interpreter tr[ying] to read a contested word or phrase that appears in the Constitution in light of another passage in the Constitution featuring the same (or a very similar) word or phrase" [3, p. 748].

11 " $[\mathrm{M}]$ istakes happen. Creating a dictionary is difficult work that requires detailed knowledge about a great many things. The lexicographer has very limited time to spend on any individual word, and it is easy to make a mistake, especially with difficult words."

12 Others have argued the intuitive position that "adding language versions to a single body of law can only be a source of confusion" [57, p. 7, citing 13, p. 251].
} 
interprete other constitutions for which contemporary translations exist-and thus should be added as a relevant tool to the constitutional hermeneutics toolkit.

\section{Method}

Our project consisted in a comparison of above-mentioned founding-era translations and the original English version of the US constitution. We have composed a comprehensive table, juxtaposing the English, German and Dutch versions [42]. Both concordances were noted, as were differences in terminology and phrasing. We have also compared the translator's choices to a number of founding-era dictionaries. The dictionaries the translator's choices were compared to were: Christoph Adelung's Grammatisch-kritisches Wörterbuch der Hochdeutschen Mundart [1], Joachim Heinrich Campe's Wörterbuch der deutschen Sprache [13], Johannes Ebers 'Vollständiges Wörterbuch der Englischen Sprache für die Deutschen [21], Johann Georg Kruenitz's Oeconomische Encyclopädie oder allgemeines System der Land-, Hausund Staats-Wirthschaft [36], Sewel's Compleat Dictionary English and Dutch [12], and Van Dale's Groot woordenboek van de Nederlandse taal [65]. We furthermore consulted The English Cellarius (1768) [70]; John Bartholomew Rogler's A Dictionary English, German And French (1763) [53], John Christian Flick's A Compleat English-German, German-English Dictionary (1763) [26], and A New English-German And German-English Dictionary Containing All Thoese Words In General Use, Designating The Various Parts Of Speech In Both Language With The Genders And Plurals Of The German Nouns. Completed From The Dictionaries Of Lloyd, Nöhden, Flügel, And Sporschil (1835) [9].

For this essay, we have selected seven passages from the US constitution and its corresponding translations. The passages were selected because they pertain to constitutional law's still ongoing discussions on the meaning of the respective phrases, and demonstrate a clear potential for the translations shedding light on the original public meaning of certain terms or phrases currently debated.

The passages also have been selected to represent our project as a whole, since they vary both in evidential value of the translators' choices and in the degree of concordance between original and translation(s). They have furthermore been selected to illustrate communalities and differences in the technique used by the translators, and its consequences for the hermeneutical potential of each translation: De Ronde's Dutch translation is notable for how closely it tracks the English-language Constitution. As Dippel describes, "This Dutch translation has a special flavor due to the fact that [De Ronde], a Dutch-American, followed the original phrasing very closely, readily adopting English terms when no Dutch equivalent seemed to be at hand, which sometimes renders the translation difficult to understand for a Dutchman" [19, p. 84 n.81]. On the one hand, De Ronde is concerned with producing a translation for a particular Dutch American readership, not a Dutch-speaking audience in the Netherlands. He could then assume of his audience some familiarity with English words and American phrases. By adhering closely to the literal meaning of the Constitution and by using congates wherever possible (instead of say, using a better-suiting, non-cognate of the English word), De Ronde was also preparing his 
audience for a future in which they would need to understand American legal terms in their American context. While by using cognates, even when these words were uncommon in Dutch, De Ronde found an easy path to providing a translation that did not have to struggle between choosing the most precise and most common Dutch equivalent of the English text. His general tendency to use cognates, however, also considerably limits the interpretative potential of his translation, since a mere cognate translation would have no hermeneutical value.

The German translator also generally followed the original phrasing of the Constitution very closely. He, however, is sometimes willing to paraphrase and extensively explain legal terminology that juridical laymen might fail to understand. And despite the translator's general verbatim style, and his close adherence to structure of the original draft even in terms of sentence structure, he also occasionally, without apparent cause, departs from his closer translation, choosing alternatives even if cognates were available. The latter tendency to sometimes avoid Anglicisms in terminology (though not in phrasing) not only heightened the text's accessability for a German reader, but also had the unintended side-effect of increasing the translation's hermeneutical potential in terms of our project of constitutional interpretation, since productive assymetries can be monitored more frequently in these passages.

The passages have also been chosen, since they not only establish evidence for the hermeneutical potential of a founding-era-translation-based approach, but also demonstrate relevant limitations of such proceeding. While in some of the articles treated both the Dutch and the German translation provide evidence for a certain understanding of a term used, the translators nevertheless occasionally differ considerably in their interpretation. Some of the translations thus do not provide evidence for an original common meaning, but might even provide evidence for a plurality of original common meanings.

\section{Application}

\subsection{Art. I, § 8, cl. 3 ("Regulate Commerce”)}

One of the most heated debates in constitutional interpretation concerns the scope of power granted to Congress under the Commerce Clause. In the past several decades, the Supreme Court has considered whether this clause grants Congress the power to mandate that every person acquire health insurance [58], to criminalize growing marijuana for one's own private consumption [60], to criminalize certain acts of violence against women [62], and to enact higher penalties for carrying a gun near a school [63]. In each of these cases, the question before the courts was whether Congress' law constituted a regulation of commerce or whether Congress had acted beyond the scope of its limited powers. Two of the more popular interpretations of the clause are represented by the work of Randy Barnett and Jack Balkin. Barnett views the original meaning of the clause as instantiating a notably limited power. In 2001, he canvased a wide variety of founding-era documents including contemporary dictionaries, records of the constitutional conventions, the Federalist Papers, and early judicial interpretations of the Commerce Clause [6, pp. 139-140]. He 
concluded that, although the term 'commerce' had a variety of meanings, in the context of the constitutional clause, commerce "means the trade or exchange of goods (including the means of transporting them)" [5, p. 146]. Barnett also concluded the verb "to regulate" meant " 'to make regular' - that is, to specify how an activity may be transacted-when applied to domestic commerce, but also included the power to make 'prohibitory regulations' when applied to foreign trade" [5, p. 146]. Jack Balkin maintains that a broader understanding of 'commerce' is appropriate. He argues that " $[\mathrm{t}] \mathrm{o}$ have commerce with someone meant to converse with them, mingle with them, associate with them or trade with them. ... The contemporary meanings of intercourse and commerce are far narrower than their eighteenth-century meanings" [5, p. 149]. "If we want to capture the original meaning of 'commerce,' we must stop thinking primarily in terms of commodities. We must focus on the ideas of interaction, exchange, sociability, and the movement of persons that business (in its older sense of being busy or engaged in affairs) exemplifies" [6, p. 151].

The German translation seems to reflect a midpoint between Barnett and Balkin's interpretations. When translating "Commerce" the translator had a number of choices: 'Commercium,' 13 'Kaufmannschaft,' 'Handel,' 'Handlung,' and 'Handelschaft.' He chose the last, 'Handelschaft,' a term that at the time already had become outmoded. ${ }^{14}$ Both Kruenitz [36], an eighteenth century encyclopedia edited between 1773 and 1858 and Adelung [1], an eighteenth century German critical dictionary edited between 1793 and 1810, define 'Handelschaft' as the business of exchanging goods with the purpose of profit. The root word of 'Handelschaft' is 'Handel,' which in its general meaning was very close to the English 'handling.' However, when used in the context of commerce, 'Handel' was understood "to broadly comprise any activity which creates a noteworthy change in an object" 15 so long as the activity was directed to profit [1]. In its common use, however, the term was usually limited "to (ex-)change of property" [1 col. 946]. ${ }^{16}$ Used as a collectivum, when the exchange of goods is someone's business, 'Handel' and 'Handelschaft' - the term the German print uses-become synonymous. From this evidence, we can draw the contours of the term's meaning. 'Handelschaft' denotes the full field of the merchants' trade, comprising exchanging goods for goods or bills, and possibly including the shipment and transportation of goods. This meaning also opens up the possibility that 'commerce' comprises the larger scope of actions and interactions of persons involved in business. The German translator could have made a

\footnotetext{
13 If "[D]as Commercium" or "das Kommerz" (the latter rather referring to covenants or contracts in general): which denotes the traffic of goods in general, and therefore is often understood as synonymous to "Handel". However, 'Handel' appears to be used much less frequently.[see 8 lemma "Kommerz", "Commercium", see also 1 col. 1342 "Commercium"].

14 According to [1], 'Handelschaft' was already outmoded as a term in the late eighteenth century. Instead, 'Handel' or 'Handlung' would be used. 'Handelschaft' is also a peculiar choice because even contemporary English-German Dictionaries usually list 'Handel' or 'Handlung' as the translation for 'commerce.'.

15 In the original commentary, "jede thätige äußere Veränderung, Nahrung und Zeitliches Vermögen zu erwerben" [1 Col. 946].

16 Kruenitz [36] understands 'Handel' in its more specific meaning as the "Business of the Merchant".
} 
different choice here: 'Kaufmannschaft,' the German cognate to the term the Dutch translation uses ('Koopmanschap'). This term would have had a narrower meaning, particularly according to S.J.E. Stosch, an eighteenth century clergyman who is known for his meditations on word-use. Stosch limits 'Kaumfannschaft' solely to the exchange of goods for money, whereas 'Handelschaft' or 'Handlung' is said to be the adequate terms for the broader scope of a merchant's action. Stosch also suggests that "Handelschaft" presupposes a business of a certain size, territorial scope and professionalism [36]. Nonetheless, often, the terms 'Handelschaft' and 'Kaufmannschaft' would be used synonymously [1]. In an English-German dictionary from 1800, Ebers defines 'commerce' as "the concourse/interaction of one with another" [21, p. 23], expressing a view similar to Balkin's. However, the German translator did not choose this locution in his translation of the Constitution. It is also notable that an even more broad term could have been used for 'commerce' - its German cognate "Commerz" or "Kommerz" (derived from the Latin "commercium" and in this form, "das Commercium", also found in German language). ${ }^{17}$ During the time of the translation, however, 'Commerz' and 'Kommerz' were not much in use. ${ }^{18}$

The Dutch translation gestures at a more circumscribed understanding of 'commerce'; his choice of 'koopmanschap' points towards the actions of 'koopmanen' (merchants). However, while the German translator had a variety of choices in how to translate 'commerce,' De Ronde had fewer options. Although 'handelschap', the Dutch cognate of the German 'Handelschaft' exists, it does not appear to have ever been in wide use. The word "koopmanschap" appears in nine places in Sewel's Dictionary, published in 1766, but "handelschap" is not found [12]. The translations of 'regulate,' however, run in different directions. De Ronde chose a Dutch cognate of the English word. In Dutch, 'regulate' or 'reguleeren' means to subject to imposition of rules or control, or to supervise. ${ }^{19}$ However, the German translator chose the verb 'einrichten,' a somewhat ambiguous term, which could mean any of: to establish something previously nonexistent, to furnish something existing, or to establish oneself somewhere. For comparison, the translator could have used the word 'regulieren,' meaning to subject something to rules or to control, now commonly used in the European Union.

While the Dutch translation preserves a narrower notion of regulation as "making regular" or setting rules for, the German translation appears to allow the government to establish commerce where it might not have previously existed. It might

\footnotetext{
17 All three versions of the cognate had two meanings: a broad one, meaning any interaction between people, be it social or directed to profit, and a narrow one, referring to the exchange of goods [see 1,8 ].

18 'Commerz' and 'Kommerz' were not much in use, and were even more rarely invoked when talking about interactions in general. This usage only later became more frequent, probably due to their frequent usage as a title to denote more noble and distinguished people, as in "Commercien-Rath" or "CommerzRath". The Prager Wörterbuch (1768) only lists "Handel", "Gewerbe" ("business") and "Bekanntschaft" ("acquaintance") as a translation of "commerce", but not "Commercium" [see also 7, lemma "Kommerz", "Commercium"; cf. 8 Col. 1342].

19 Specifically, "reguleeren" means "[t]o make regular or orderly" as in "to regulate the course of a river", also "to subject to legal decisions and rules" [see 17].
} 
be argued that the Commerce Clause ruling in the constitutional challenge to the Affordable Care Act, which concerned whether Congress had the power to force individuals to engage in commerce, might have had a different result if the German translation were the dispositive text.

\subsection{Art. II, § 1, cl. 5 ("Natural Born Citizen")}

Art. II, $\S 1$, cl. 5 stipulates that only "a natural born Citizen, or a Citizen of the United States, at the time of the Adoption of this Constitution, shall be eligible to the Office of President." Recent presidential elections have raised the question of what it means to be a "natural born Citizen". The Republican presidential candidate in 2008, John McCain, was born to American parents in the Panama Canal Zone in 1936, while his father was on active duty in the U.S. Navy [15, p. 2]. Before McCain, a shadow was also cast on George Romney's attempt to win the Republican presidential nomination in 1968; Romney was born in Mexico to U.S. citizen parents [60, p. 43].

There are competing interpretations of the phrase "natural born Citizen". Gabriel Chin argues that to be a natural born citizen, one must be a citizen "at the moment of birth", whether or not that citizenship is acquired under the citizenship clause of the Fourteenth Amendment or by congressional statute [15, p. 2]. A competing view is that one is only a natural born citizen if one is born within the United States. Under this view, a child who is born to American citizens abroad is naturalized at birth by a Congressional statute and is not a natural born citizen [15, p. 5]. Still another view holds that the citizenship clause of the Fourteenth Amendment is not the right place to look for the definition of "natural born Citizen", as the Fourteenth Amendment was passed after the constitution was adopted, and that the notion of "natural born Citizen" can be extracted from the common law [15, p. 16]. Larry Tribe and Ted Olson claim the "natural born Citizen" language contemplates the inclusion of children of American citizens, arguing that the clause was inspired by the British Nationality Act of 1730 , which provided that children born abroad to "natural-born Subjects" of the British crown were "natural-born Subjects" themselves [63]. In Tribe and Olson's view, the Natural Born Citizen Clause tracks the existing understanding of natural born subjects in England, simply substituting the word "Citizen" for "Subject" [63], see also, e.g., [31, pp. 34-35]. Larry Solum similarly looks to Blackstone's discussion of "natural born subjects" as an indication of what people during the founding might have looked to in order to understand the phrase "natural born Citizen" [59, p. 107]. However, Blackstone is "not completely clear or precise" [31, p. 27]. Blackstone states, "Natural-born subjects are such as are born within the dominions of the crown of England" [10, p. I: 366]. But he also qualifies the statement, noting "all children, born out of the king's ligeance, whose fathers were natural-born subjects, are now natural born subjects themselves, to all intents and purposes" [59, p. 27]. ${ }^{20}$

\footnotetext{
${ }^{20}$ Other evidence cuts both ways. The first naturalization act of 1790 provides "children of citizens of the United States, that may be born beyond sea, or out of the limits of the United States, shall be considered as natural born citizens" [63, p. 29]. On the one hand, this statute could be read as simply codifying the original meaning of the natural-born citizenship clause. On the other hand, it could be seen as setting
} 
De Ronde translates "natural born Citizen" to "ingeebooren burger" (an inborn or innate citizen). As written, De Ronde's language is close to a word-for-word literal translation of the English text, but in Dutch the language becomes somewhat redundant, since the Dutch term for citizen is a case of Jacobson's dictum that "languages differ essentially in what they must convey and not in what they may convey" [67, p. 66]. Whereas English only has one term for citizens, eighteenth century Dutch splits the concept into two terms - one for citizens at birth, and another for naturalized citizens. ${ }^{21} \mathrm{~A}$ 'burger' meant a person who was a citizen automatically or at birth, as contrasted to a 'porter,' who was a naturalized citizen. The different terms arose from a physical understanding of Dutch cities. At the center of old Dutch cities was a fort (burg or burcht, the same root existing in the French adjective bourgeious); the "poort" was the gate into the city. One thus belonged truly to the center of the city, or one was admitted from the outside. The choice of "ingeebooren" could indicate De Ronde's belief that a citizen needed to be born in the United States, or the entire phrase could simply be understood as an imperfect attempt to literally translate the English text, as De Ronde does at many points in the Dutch copy.

The German translation gestures at the broader interpretation of the Natural Born Citizen Clause, using the phrase "ein geborner Bürger".

The term has a similar origin as the Dutch term: A 'Bürger' belonged to a privileged group in urban society, he was neither noble nor clergy, but nevertheless had, unlike the rest of the population, certain freedoms and rights. These rights had to be granted-and usually were granted to inhabitants of free cities. Although 'Bürger' is thus not a perfect substitute for 'citizen', ${ }^{22}$ it could nevertheless be commonly used in this way during the eighteenth century, especially when translating the Latin term 'civis' or the English 'citizen". ${ }^{23}$ In terms of semantics, however, the situation of the German translator differed considerably from the Dutch, since a term equivalent to the Dutch "porter" did not exist, limiting the translator's options, and thus the hermeneutical potential of his choice.

In his translation, the German translator furthermore dropped the 'natural' entirely. Why did the translator omit the word 'natural'? One possibility is that the translator believed the notion of "natural born" was completely captured by

\footnotetext{
Footnote 20 (continued)

a discretionary rule beyond that which a common law notion of "natural born citizen" or "natural born subject" would include [58]. Given the ambiguous evidence, Solum gestures towards the "New Originalist" notion that there can be a point where "interpretation runs out" and sources beyond the Constitution's text and the original public meaning of the document must be looked to [see 63, p. 30].

21 Sewel's 1766 dictionary equates the status of "burger" to one who is free. So, for the English word "infranschise", he says, "(or to make a freeman) iemand burger maaaken" [11, p. 386].

22 At least not in the sense of Jean-Jacques Rousseau's juxtaposition of "bourgeois" and "citoyen".

23 Adelung lists a number of different meanings of the term 'Bürger': first, a Bürger is defined as an inhabitant of a city whose inhabitants were allowed to partake in the freedom the town itself had (the word is traced back to "Burg" which is understood to refer to any fortified place); second, as the so-called "third estate", in contrast to the nobles and clergyman; third, as a translation for the Latin "civis", in a republic or a comparable form of state; and fourth, in a figurative meaning, anyone living in a town [1 col. 1263-1264].
} 
"geborner", that he could not conceive of how someone who was "born a citizen" would not be a "natural born citizen", and that he understood such tautology in the original simply as a rhetorical cliché. Ersch-Gruber [23], an early nineteenth century German Encyclopedia, includes the statement that "every son of a citizen is a born citizen" [23, p. 39]. ${ }^{24}$ Naturalization or birth thus were the only two ways of becoming a "Bürger", tertium non datur, and due to the blood principle, a child born oversees didn't need to be naturalized. ${ }^{25}$ Notably, in German-language discussions of the Natural Born Citizen clause during the early nineteenth century, the "natural" is usually omitted. ${ }^{26}$ " $[\mathrm{N}]$ atural born" is simply understood to stand in contrast to the case of adoption (and the special case of residence in part of Missouri at the time of the French cession) $\left[52\right.$, p. 304]. ${ }^{27}$

\subsection{Art. II, § 2, cl. 3 ("Recess")}

In January 2012, President Obama appointed Richard Cordray to head the newlycreated Consumer Financial Protection Bureau ("CFPB"), as well as three other individuals to the National Labor Relations Board ("NLRB”) [46]. Cordray's nomination had been blocked by a Senate filibuster since July 2011 [46]. The President had acted during what the executive claimed was a "Recess of the Senate", permitting him to bypass the requirement to receive the "Consent of the Senate". At the time of the appointments, the Senate was meeting in pro forma sessions every three business days from December 20, 2011, through January 22, 2012, rather than officially ending the legislative session [64]. Often the meetings lasted "minutes or even seconds ... to meet the definition of holding a Congressional meeting" [46]. Senate Democrats had used the same tactic in the past to prevent President Bush from making recess appointments [46]. The question of whether President Obama's appointments qualified as occurring "during the Recess" made its way to the Supreme Court and was answered in June 2014 in the decision National Labor Relations Board $v$. Noel Canning. All nine justices held that the appointments were unconstitutional, however they disagreed on why. Writing for the majority, Justice Breyer held that the term 'the Recess' includes both the intersession recess between Senate sessions and "an intra-session recess of substantial length" [43, pp. 2550, 2561]. The

\footnotetext{
24 Jeder Bürgersohn ist geborner Bürger, für Fremde aber ist die Bürgerannahme mit großen Schwierigkeiten verbunden.

25 It is noteworthy here that rules seem to differ respecting the classes/estates. Being a peasant and being a nobleman was evidently a question of birth, but naturalization initially seems to have been the major form of becoming a "Bürger" (later also here the blood principle was applied). Nevertheless, in both cases the choice was disjunctive: you were either a born into your estate or naturalized.

26 If, at the time in Germany, the phrase "naturally born" was ever used outside the context of the United States Constitution, then it was either in a theological context (distinguishing the natural birth from the rebirth by faith, or contrasting the naturally born humans from the god-made Adam) or in a medical context (obstetrics).

27 This German volume contains a brief summary of the United States Constitution. In [68], a translation itself, a similar omission can be found: "The American Certificate of Naturalization grants foreigners, who have been domestic there for seven years, all rights of inborn subjects" [68, p. 424].
} 
majority understood the purpose of the clause as preventing governmental action from grinding to a halt during the Senate's extended absence. ${ }^{28}$ As the D.C. Circuit noted in the same case, "At the time of the Constitution, intersession recesses were regularly six to nine months ... and senators did not have the luxury of catching the next flight to Washington" [47, p. 503]. Although the President could hypothetically exercise the recess appointments power during an intra-session break of the Senate, the Court deemed the three-day break at issue was too short to constitute a break that would activate the recess appointments power [43, p. 2566]. In contrast, Justice Scalia's concurrence maintained that the term 'the Recess' could only refer to the single intersession recess that occurred between formal legislative sessions" [43, p. 2592]. "[I]f 'the next Session' denotes a formal session, then 'the Recess' must mean the break between formal sessions" [43, p. 2596].

De Ronde translates the recess clause to "gedurende de afweezenthyd van de Senaat"-or "during the extended absence of the Senate". In other Dutch documents from the period, the word 'afweezenthyd' is used when an official or member of royalty is absent from a place for months or years, such as when one is on an extended trip abroad. In this sense, it is different from the modern Dutch 'afwezigheid' which refers more generally to one's absence, or to one being merely "not present", such as when one does not attend a business meeting. De Ronde's choice of 'Afweezenthyd' indicates that he interpreted the original to mean that the absence was more than immediate or temporary but extended.

The Dutch translation gestures at the underlying purpose of the Recess Clauseto give the President the power to get work done when the Senate was absent for an extended period of time and, by extension, could not approve a candidate. Because of the difficulty and slow pace of travel in the late eighteenth century, senators would literally be unable to approve nominees when they left the Capitol to return to their home states. The Recess Clause would have allowed the President to temporarily fill vacancies during periods when the senators were absent for an extended period of time.

In contrast, the German translation brings less clarity to the Noel Canning question. Although most of the German translation of the Constitution is literal, the Recess Clause is paraphrased. "[D]uring the recess of the Senate" became "da der Senat nicht sitzt"- "when the Senate is not sitting". In the same manner the German translator circumscribes "recess" in Art. II, § 2, cl. 3. The definite article- "the Recess"-is absent from the German translation. And the 18th-century German distinction between 'séance' and 'session'-the former meaning the individual meeting, the latter the longer period of time convened, including adjournments-does not provide much guidance because "to sit" is the root of both nouns. ${ }^{29}$

\footnotetext{
28 "[The framers] might have expected that the Senate would meet for a single session lasting at most half a year" [43, pp. 2565-2566]; "[T]he majority contends that the Clause's supposed purpose of keeping the wheels of government turning demands that we interpret the Clause to maintain its relevance in light of [new circumstances]" [43, p. 2598 Scalia, J., concurring].

29 Accordingly, Delacroix can write: "Session is the row of meetings until an Ajournement, therefore Session and Séance are not to be confused" [16, p. 320]. However, these terms were often treated as synonymous. In the case of Delacroix, the German Translator equates "Sitzung" and "séance". Nonetheless, the session is usually understood not as a single meeting, but as longer period [1], for this gives the word
} 
Nonetheless, the German translator's choices can contribute to the discussion. Although he uses "sitting" in the sense of "séance" in Art. I, § 3, cl. 6, his understanding of the word 'recess' becomes clearer when paraphrasing it in Art. I, § 3, cl. 2. In that clause, "recess" is understood as the interim period after the assembly has parted ("während der Zeit, da ... auseinandergegangen ist") until the next "comingtogether" (the literal meaning of "Zusammenkunft"). However, only so much can be read into this phrasing, because the translator also uses "Zusammenkunft" in the case of adjournment [35 Art. II, § 3].

\subsection{Art. I, § 6, cl. 1/Art. I, § 8, cl. 10/Art. IV, § 2 ("Felony")}

Another discussion concerned the constitution's use of the term "felony". The term has had a very broad and frequently changing meaning. Writing in 1823, Massachusetts lawyer and legislator Nathan Dane wrote in his treatise on American law, "[T] he word felony, in the process of many centuries, has derived so many meanings from so many parts of the common law, and so many statutes in England, and has got to be used in such a vast number of different senses, that it is impossible to know precisely in what sense we are to understand this word" [17, p. 715]. Although felonies were traditionally punished by forfeiture of property or death under the common law in England, in America at the time of Dane's writing, there were "many felonies, not one punished with forfeiture of estate, and but a very few with death" $[17$, p. 715$]$. Blackstone similarly explained, "Felony, in the general acceptance of our English law, comprises every species of crime, which occasioned at common law the forfeiture of lands or goods" [10, p. 94].

For "felony", the German translator chose the word "Hauptverbrechen" (capital felony). In the present day, the term is no longer in use. ${ }^{30}$ In the tradition of the early penal codes and its translations, ${ }^{31}$ it meant "head crime"- - one automatically punished by death, usually decapitation. ${ }^{32}$ Like the English term 'felony,' 'Hauptverbrechen' had already experienced a considerable semantic shift in Germany by the late eighteenth century, and the translator could have intended the term to encompass a variety of meanings. Most likely, he intended a more modern meaning, since fundamental changes in the penal system had already severed the direct link between the gravity of the offense and the punishment. ${ }^{33}$ The secondary meaning "Haupt-"

\footnotetext{
Footnote 29 (continued)

"Sitzungsperiode" (or "session"). The single meeting in contrast would be called "séance". By using the verb, the German translator avoids having to choose the right noun (and by this does not need to decide between interpretations).

30 A cognate of 'Hauptverbrechen,' 'Kapital-Verbrechen' might still be found, especially as a layman's term. Another term frequently used today is 'Haupttat,' also translating to "capital crime", but which is presently used to distinguish the crime of the main perpetrator from that of the accessory.

31 The Latin "res capitalis" and "pecccatum mortale" would usually translate as "Haupt"- or "CapitalVerbrechen".

32 For example, the "Constituito Criminalis Carolina" of 1532 was colloquially called "Halsgerichtsordnung" ("throat criminal code"), since the usual punishment in the Carolina was death.

33 A key change in Germany was to render punishment that was not only adequate to the crime committed, but also appropriate in light of a perpetrator's individual level of guilt.
} 
always possessed outside the field of criminal law ("main") had largely replaced the primary meaning ("capital") even in the field of penal law [1, p. 572]. In contract law, "Haupt-Pflicht" ("capital duty") was already understood to be the main duty of a party, and in the Field of Ethics, "Haupttugend" ("capital virtue") could stand in for "Kardinaltugend" ("cardinal virtue") [1 col. 1019]. When Campe's Dictionary defines "Hauptverbrechen" in 1808, there is no explicit reference made to the deathpenalty. Instead the term is defined as "a grand, grave crime (capital crime)" [13, p. 192], although German legal scholars of the early nineteenth century would still have to debate what was meant when interpreting a law that uses the term. ${ }^{34}$ When Johann Joachim Eschenburg used the term in 1783, he stated that the usual punishment for murder, as a capital crime, was banishment, a statement which would be contradictory if "Hauptverbrechen" required the death penalty [24]. ${ }^{35}$

Evidence that such semantic shift was taking place is particularly visible in a German translation of the proposed Seventh Amendment (which became codified as the Fifth Amendment) from the early 1800s. The phrase "capital, or otherwise infamous crime" is simply translated as "Haupt-Verbrechens", illustrating that the term could serve as a translation for both "capital crimes" in the literal sense, and those crimes that are "as infamous" as such crimes [50, pp. xx-xxii]. ${ }^{36}$

In the Dutch translation, despite the allegedly amorphous meaning of 'felony,' De Ronde used a strikingly unambiguous term in translation. De Ronde translated "felony" to "doodwaardige misdaaden"-literally, "crimes worthy of death" (except in Article IV, § 2, where he curiously says "felony", without translation). De Ronde's choice particularly suggests that despite the vague meaning of 'felony' before and after the founding, some individuals might have still understood it as having a clear, narrow meaning-namely, a capital crime.

\subsection{Art. IV, § 2, cl. 1 ("Privileges and Immunities")}

The so-called Privileges and Immunities Clause reads: "The Citizens of each State shall be entitled to all Privileges and Immunities of Citizens in the several States." There are two frequently encountered interpretations of this clause. The first is that the clause merely prevents discrimination between residents and nonresidents of a state- "the Clause guarantees that nonresident citizens will have merely the same privileges and immunities that are guaranteed to resident citizens" [55, p. 890].

\footnotetext{
34 For example, in Bavaria in the 1850's, the question arose of whether "capital crimes" in the Bavarian Criminal Code of 1813 meant only those crimes that were punished with death. At first glance, this debate might point against the modern use. However, the text presumes that people (already) used the term in the more modern sense of "severe crime", this being the reason why there was need for the debate at all.

35 Eschenburg's subject is Greek antiquity, so it does not say much about the use of 'Hauptverbrechen' in a more modern legal context. Nevertheless, it is significant that the author can use the term in such context (meaning for a crime that was in general not punished with death, but with a different punishment) without being contradictory.

36 Two other nineteenth century translators of the U.S. Constitution into German completely omit the word "Capital" in their translations [see 22, p. 84 n. 86].
} 
The second is that the Clause "guarantees a uniform set of substantive privileges and immunities to citizens of the United States no matter what rights a particular state constitution might contain" [55, p. 890, [4, p. 5]. ${ }^{37}$ Supreme Court jurisprudence currently treats the Privileges and Immunities Clause as a non-discrimination clause, preventing the governments of a state from discriminating against citizens from other states. Under this interpretation, the phrase "Privileges and Immunities" does not consist of specific protections of substantive rights, but rather requires that any "Privileges and Immunities" granted or recognized by a state are granted or recognized equally in citizens of that state and of other states.

The question of what laws were "necessary" quickly became salient after the founding, when each branch of government considered whether Congress had the power to charter a bank. While Alexander Hamilton took the view that "necessary often means no more than needful, requisite, incidental, useful or conducive to" [30, pp. 97-98], James Madison, Thomas Jefferson, and Edmond Randolph interpreted "necessary" in a narrow manner [6, pp. 158-166]. When Chief Justice John Marshall ruled on the constitutionality of the Bank of the United States in 1819, he sided with Hamilton. To Marshall, "necessary" meant "convenient". ${ }^{38}$ Although Marshall weaved flexibility into the notion of necessity, he suggested that "necessary" laws must still remain incidental in character. ${ }^{39}$ Marshall went on to suggest that the term 'proper' limited Congress to passing laws actually, rather than pretextually, aimed at achieving the ends listed among the enumerated powers [see 6, pp. 184-189]. ${ }^{40}$

De Ronde's translation of "privileges" to "voorregten" reflects the notion that privileges were benefits granted by the state, instead of rights. For "immunities", De Ronde uses "vryheden" (freedoms), a word that reflects a notion of natural liberty rather than a special grant by the state. Sewel's Dutch-English Dictionary from 1766 attests that "voorrecht" is a special privilege, and that freedom (vryheid) is a more general term [12]. Where the term 'privilege' is used in Article 1, Sect. 9, clause 2,

\footnotetext{
37 The substantive view is perhaps most famously associated with a judicial opinion Corfield v. Coryell [73], written by Justice Bushrod Washington while riding circuit. Many scholars understand Corfield as standing for the proposition that "the privileges and immunities protected under Article IV are not those graciously accorded to its citizens by a state of sojourn, but the rights, privileges and immunities of citizens of the several or United States-the natural, fundamental rights of free men everywhere" [4, p. 11].

38 Marshall wrote,

[I]n the common affairs of the world, or in approved authors, we find that ['necessary'] frequently imports no more than that one thing is convenient, or useful, or essential to another. To employ the means necessary to an end, is generally understood as employing any means calculated to produce the end, and not as being confined to those single means, without which the end would be entirely unattainable [41, pp. 413-414].

39 Part of Marshall's rationale for holding the bank constitutional was that the power to charter a bank was not "a great substantive and independent power, which cannot be implied as incidental to other powers, or used as a means of executing them" [41, p. 411].

40 Marshall wrote,

[S]ound construction of the constitution must allow to the national legislature that discretion, with respect to the means by which the powers it confers are to be carried into execution, which will enable that body to perform the high duties assigned to it, in the manner most beneficial to the people. Let the end be legitimate, let it be within the scope of the constitution, and all means which are appropriate, which are plainly adapted to that end, which are not prohibited, but consist with the letter and spirit of the constitution, are constitutional [46, p. 421].
} 
describing the "privilege of habeas corpus", De Ronde chooses the cognate "privilegie" to stand in for privilege.

The German translator also gives a meaning to "privileges and immunities" that is not quite in accord with existing theories, but which is notably aligned with the meaning evoked in De Ronde's translation. For "privileges", he uses "Vorrechte", meaning a special benefit granted, and for "immunities", he uses "Freyheiten" ('freedoms'). This understanding, however, clearly is in conflict with the German translator's use in Art. I, $\S 9$, cl. 2: "The Privilege of the Writ of Habeas Corpus", is translated as the right of habeas corpus- "Das Recht des Habeas Corpus", now equating "privilege" ("Vorrecht") and the more modern "right" ("Recht").

\section{Conclusion and Limitations}

The above should be sufficient to demonstrate the potential of a translation approach for the task of recovering the original public meaning of the US constitution. Because translation presupposes interpretation, the particular choices of the translators can be understood as founding-era commentaries on the Constitution. Commentary is not only present where the translators paraphrased or even chose to substitute a technical term with an extended explanation. Rather, the translator's choice of words and sentence structure itself inherently reflects analysis. The fact that languages are far from isomorphic, that in a large number of cases the translator had the ability or need to choose from among many terms or phrases with varied meanings, sheds light on how a member of the founding-era public would have understood the English-language text. Indeed, the passages we treated in this paper collectively illustrate a range of views that the founding-era public might have had about the content of the Constitution.

This evidence, however, is not limited to the above treated passages. A larger number of passages of the translations can be used as evidence for a founding-era understanding of terms currently still under debate. In addition to the questions treated above, our translation approach has also proven to be able to provide evidence for a certain founding-era meaning of a term or phrase regarding a number of other current debates, such as the discussion on the meaning of the term "certain" of the Progress Clause (Art. I, $\S 8, \mathrm{cl} .8$ ), and the meaning of the term "necessary and proper" in Art. I, $\S 8, \mathrm{cl}$. 18. In both these cases, it was the translator's choice of a specific word that provided evidence for a certain understanding of a term. In the first of these two cases, the translators' choices enlightened whether the term "certain" requires a fixed, thus definite timespan, a question pertinent to Eldred $v$. Ashcroft, 537 U.S. 186 (2003) [22]. In the other case, de Ronde's decision not to choose a cognate assisted in illuminating the question whether "proper" indicated that laws must accord with the government's fiduciary duty to the people [44, pp. 52, 108-109].

Our discussion, however, also highlighted a number of limitations present when using the founding-era translations as an interpretive tool. The issues range from 
how authoritative a translator's understanding of a legal text can be, ${ }^{41}$ to how conscious the translator was of the nuanced meaning of his choices.

Furthermore, the quality of our translators' work in general is far from being beyond doubt. Although De Ronde, the Dutch translator, had learned to preach in English, at least in his early years he was criticized for being "not in the least qualified" to do so [22, p. 65]. Historian Joyce D. Goodfriend observes, "How widely De Ronde read in English remains a matter of conjecture, but he clearly read well enough to be conscious of contemporary English literary conventions. Yet... it is not surprising that he exhibited concern about his comprehension of English" [29, p. 67]. De Ronde himself described his English-language book A System: Containing the Principles of Christian Religion, Suitable to the Heidelberg Catechism as "a bold Undertaking, by a person so little versed in the English Language" and continued: "[I]t would be Presumption to pretend to write it [in English] with Ease and Elegance" [22, p. 67]. In another English-language book, The True Spiritual Religion, he wrote that "flowers of rhethorick, fine style, fancy, wit, and such other ornaments" were "more than my skill in the English language could produce" [22, p. 68]. His translation of the constitution was also criticized early on: In 1793, a Dutch legal scholar chose to translate the text again, rejecting De Ronde's translation as "flawed in its execution" [20, p. 707].

The reception of De Ronde's other work also suggests that he sometimes traded conscientiousness for speed. After printing his book A System: Containing the Principles of the Christian Religion, Suitable to the Heidelberg Catechism, De Ronde was "admonished for leaving out an essential piece of doctrine" by the Amsterdam Classis [22, p. 65]. De Ronde explained that "his eagerness to see the work in print precluded sending the manuscript to Amsterdam for approval" and that he would add an appendix containing the missing material to the work [22, p. 65].

Though, in contrast, not much is known about the German translator, a number of things can be deduced about his person from his translations, some of which also entail noteworty limitations. There are indications that he was a Southern German native speaker. ${ }^{42}$ His word use is elevated, and he likely did not, or did not always, use a dictionary, since some of his translations are not the obvious choice if compared to contemporary dictionaries. ${ }^{43}$ The latter is especially the case when it comes to more technical terms: here his choices often are far from what the dictionaries of the time would have listed. ${ }^{44}$ Some of his vocabulary also appears dated, especially

\footnotetext{
41 An issue most pertinent in the translation of the Necessary and Proper Clause.

42 In one instance, he even uses a word that was only common in some German dialects: The translator uses the word "zween", which is the male variant of "two", a distinction that was only present in some parts of Southern Germany. It could however also be a typo ("zween" instead of "zweien"), but the grammatical case and the gender match better in the case of "zween".

43 E.g., in Art. $2 \S 1$ "inability" is translated as "incapability"; "qualification" is translated as "Tüchtigkeit" (competence, efficiency) in Art. $1 \S 5$, and as "property" in Art. I $\$ 2$ cl. 1. Even clear translation errors are present: In Art. I $§ 9$, ,,suspended “ is translated incorrectly as ,,aufgehoben “ (abrogated) instead of using the correct term "aufgeschoben". In Art. VI, the translator confuses "contracted" and "contract".

44 Apart from the examples listed supra note 44, "bill" seems to be a recurring problem for the German translator. The term is however listed by Ebers (1704) as a loanword [21]. Translating "to try" and "trial"
} 
when it comes to terms of law and commerce. ${ }^{45}$ Whether the translator was a lawyer is unclear but seems doubtful, since dealing with legal language is where his German vocabulary occasionally fails. There is much more than a basic knowledge of grammar present, ${ }^{46}$ although the translator often chooses to ignore his knowledge when it comes into conflict with his metaphrasing style. ${ }^{47}$ His attempt to keep the sentence structure of the original text and at the same time to obey the most basic rules of German grammar often creates monstrous hybrids that, especially when it comes to longer passages, are hard to understand even for a German reader. On rare occasion, the translated sentence is distorted so severely that the meaning can only be reconstructed by using the immediate context. ${ }^{48}$ And repeatedly, the translator demonstrates a lack of consistency when translating one and the same term (or closely related words). It is unclear, whether such sprung from negligence, from a need for expediency, or from another translator assisting in the matter. It might, in general, have been simpler to use cognates, translate line by line, sentence by sentence, halfsentence by half-sentence, and occasionally adjust the grammar to the German rules, than to change the sentence structure in a way to facilitate understanding. That time pressure or other economic considerations might have affected the translation could be supported by his permitting of the phrasal monsters he created to remain in the translation (along with recurring omissions of complete words), ${ }^{49}$ as well as the fact that some of the more ill-fitting word-choices might have resulted from failing to consult a dictionary.

There is not enough evidence to decide the latter issues, but both his consistency as well as his inconsistencies nevertheless are equally noteworthy; they have to be taken into account as limitations when the translator's choices are used to interpret the original meaning of the English original.

Further limitations of using founding-era translations to interpret the original text are most clearly apparent in those cases where our translators in fact disagree on the meaning of a passage. Although, e.g., the German translations of "high Crimes" and "felony" track the dominant academic and contemporary understanding of the terms,

Footnote 44 (continued)

(as, e.g., in Art. I $\S 3$ and Art. II $\S 2$ cl. 12) also seems to have been a challenge for the German translator.

45 See, e.g., supra note 17. Other examples are the term "Verwillung" as a translation of "consent" in Art. I $§ 9$ and the use of the term "worzu", a dated form of "wozu" in the same paragraph. However, also De Ronde's language sometimes seems old-fashioned, e.g., in the use of "bekwaam" vs. "bequaam". See [12], where "bekwaam" outpaces "bequaam" 38 to 2 in appearances.

46 The translator's knowledge of German is particularly on display when it comes to using the correct genitive case; also, the correct position of the verb and auxiliary verb is frequently chosen, something non-native speakers often have difficulty with.

47 Metaphrase is the word-for-word, line-for-line rendering of a text, as contrasted with paraphrase [see 42, p. 1194, citing 32].

48 One example is Art. $1 \S 7 \mathrm{cl} .2$, another example is the translation of "and all treaties made" in Art. VI.

49 The word "may" is frequently omitted in his translation (e.g., in Art. I $§ 5$ ), and words in the singular are repeatedly turned into the plural form (and vice versa), e.g., in Art. I $§ 5$ ("times") and Art. I $\S 8$ ("law(s)", "power". In Art V, when translating "purpose and intent", "purpose" is omitted in the German translation. 
De Ronde's translations deviate sharply from those interpretations. His translation of "high Crimes" evokes severity rather than a crime against the state; similarly, his translation of "felony" - "crime worthy of death" - is both highly specific and at odds with existing English and American law. Such semantic dissociation between the two translations can be understood as either an example of differing interpretations, or as a contingent result of the translation process as a more or less conscious and controlled activity that inevitably leads to differences. The latter possibility might often be the case with these translators' work. The fact that even within their own translations, certain terms are not applied in a consistent way calls into question the usefulness of understanding every word-choice as an interpretative argument.

It is also worth recognizing that agreement between the translators does not necessarily indicate that their interpretations reflected the founding-era public. Agreement could spring from a consensus on the meaning of a respective passage, but could also simply be a case of coincidence. Concord in these cases does nevertheless have a significant heuristic value: there is a good chance that the translations agree with each other for a reason. Coupled with the translations' historic value, these insights render the founding-era translations of the United States Constitution a relevant source for constitutional scholars and lawyers today. And even in the case of disagreement, the translations still can serve as a piece of the interpretive puzzle and add to our understanding of the Constitution as a whole: Despite any ambiguities, the translations provide additional evidence of the Constitution's original public meaning — including a possible plurality of original common meanings - and ought to stand alongside contemporary news articles, commentaries, convention notes, and dictionary definitions.

Acknowledgements Open Access funding provided by Projekt DEAL. Where uncited, interpretation of Dutch was completed by Michael Douma and interpretation of German was completed by Hans Lind. This paper is a condensed and modified version of the concluding publication of a joint research project initiated at Yale Law School, originally published as a 102-page paper under a non-exclusive license. The authors wish to thank Jack Balkin, William Baude, Randy Barnett, Randy Beck, Jud Campbell, Nathan Chapman, Dan Coenen, Bill Glod, Christopher Green, Jeanne Hoffman, Martin Kagel, Kurt Lash, Robert Leider, Michael McConnell, Tim Meyer, Joe Miller, Thomas E. Mulligan, George Pike, Richard Re, Bo Rutledge, Stephen E. Sachs, Frederick Schauer, Larry Solan, Larry Solum, Christian Turner, Kirk Wetter, the faculty workshop participants at the University of Georgia, the fellows of the Information Society Project at Yale Law School, and the participants in the Sixth Annual Hugh \& Hazel Darling Foundation Originalism Works-in-Progress Conference. Special thanks to Michael Widener, Rare Book Librarian \& Lecturer in Legal Research at the Lillian Goldman Law Library at Yale Law School, for his invaluable research help, without which this project could not have been completed.

\section{Compliance with ethical standards}

Conflict of interest The authors declare that they have no conflict of interest.

Open Access This article is licensed under a Creative Commons Attribution 4.0 International License, which permits use, sharing, adaptation, distribution and reproduction in any medium or format, as long as you give appropriate credit to the original author(s) and the source, provide a link to the Creative Commons licence, and indicate if changes were made. The images or other third party material in this article are included in the article's Creative Commons licence, unless indicated otherwise in a credit line to the material. If material is not included in the article's Creative Commons licence and your intended use is not permitted by statutory regulation or exceeds the permitted use, you will need to obtain permission 
directly from the copyright holder. To view a copy of this licence, visit http://creativecommons.org/licen ses/by/4.0/.

\section{References}

1. Adelung, Christoph. 1970 [1793]. Grammatisch-kritisches Wörterbuch der Hochdeutschen Mundart mit beständiger Vergleichung der übrigen Mundarten, besonders aber der oberdeutschen. Zweyte, vermehrte und verbesserte Ausgabe. reprint ed. Hildesheim, NY: Georg Olms Verlag.

2. Akademie, Berlin-Brandenburgischen, and der Wissenschaften (eds.). 1978. Goethe-Wörterbuch. Stuttgart: Verlag Kohlhammer.

3. Amar, Akhil. 1999. Intratextualism. Harvard Law Review 112 (4): 747-827.

4. Antieau, Chester. 1967. Paul's Perverted Privileges or the True Meaning of the Privileges and Immunities Clause of Article Four. William and Mary Law Review 9 (1): 1-38.

5. Balkin, Jack M. 2011. Living Originalism. Cambridge, MA: Belknap Press.

6. Barnett, Randy. 2001. The Original Meaning of the Commerce Clause. University of Chicago Law Review 68 (1): 101-147.

7. Bellos, David. 2011. Is That a Fish in Your Ear? Translation and the Meaning of Everything. New York: Faber and Faber.

8. Benjamin, Walter. 2000 [1923]. The Task of the Translator. An Introduction to the Translation of Baudelaire's Tableaux Parisiens. In The Translation Studies Reader, ed. Lawrence Venuti, 15-25. London: Routledge.

9. Bernays, Adolphy. 1834. A New English-German and German-English Dictionary. Philadelphia: George W. Metz and Son.

10. Blackstone, William. 1765-1769. Commentaries on the Laws of England. Oxford: Clarendon Press.

11. Bobbitt, Phillip. 1982. Constitutional Fate: Theory of the Constitution. New York: Oxford University Press.

12. Buys, Egbert. 1766. A Compleat Dictionary English and Dutch to which is added a Grammar, for both Languages, originally compiled by William Sewel; But now, not only reviewed, and more than the half part augmented, yet according to the modern spelling, entirely improved by Egbert Buys. Amsterdam: Kornelis de Veer.

13. Campe, Joachim Heinrich. 1808. Wörterbuch der deutschen Sprache. Zweyther Theil. Braunschweig: In der Schulbuchhandlung.

14. Cheung, Eric. 2000. Bilingualism: Where are we heading? In Reform of the Civil Process in Hong Kong, ed. Michael Wilkinson and Janet Burton, 241-252. Singapore: Buttersworths Asia.

15. Chin, Gabriel. 2008. Commentary, Why Senator John McCain Cannot Be President: Eleven Months and a Hundred Yards Short of Citizenship. Michigan Law Review First Impressions 107: 1-21.

16. Croix, Jacques-Vincent. 1792. Verfassungen der vornehmsten europäsischen und der vereinigten amerikanischen Staaten. Aus Dem Französischen mit Berichtigungen des Uebersetzers. Leipzig: Weidmann.

17. Dane, Nathan. 1823. Digest of American Law. Boston: Cummings, Hilliard \& Co.

18. Diffenderffer, Frank. 1977. The German Immigration Into Pennsylvania. Baltimore: Genealogical Publishing Co.

19. Dippel, Horst (ed.). 2006. Constitutions of the World from the late 18th Century to the Middle of the 19th Century/Verfassungen der Welt vom späten 18. Jahrhundert bis Mitte des 19. Jahrhunderts. New York: De Gruyter.

20. Douma, Michael. 2019. Two Early Dutch Translations of the United States Constitution: Public Meaning in a Transnational Context. Law and History Review 37 (3): 707-723. https://doi. org/10.1017/s0738248019000403.

21. Ebers, Johannes. 1794. Vollständiges Wörterbuch der Englischen Sprache für die Deutschen. Leipzig: Johann Gottlob Immanuel Breitkopf Sohn und Compagnie.

22. Eldred v. Ashcroft, 537 U.S. 186 (2003) 2003.

23. Ersch, Johann Samuel, and Johann Gottfried Gruber (eds.). 1821. Allgemeine Encyclopädie der Wissenschaften und Künste in alphabetischer Folge von genannten Schriftstellern bearbeitet. Leipzig: Johann Friedrich Gleditsch. 
24. Eschenburg, Johann Joachim. 1783. Handbuch der klassischen Literatur. Berlin: Bey Friedrich Nicolai.

25. Fallon, Richard. 1987. A Constructivist Coherence Theory of Constitutional Interpretation. Harvard Law Review 100: 1189-1286.

26. Flick, John Christian. 1763. A Compleat English-German German-English Dictionary. Leipzig: John Frederick Gleditsch.

27. Frost, William. 1955. Dryden and the Art of Translation. New Haven: Yale University Press.

28. Gonzales v. Raich, 545 U.S. 1 (2005) 2005.

29. Goodfriend, Joyce D. 1999. Incorporating Women into the History of the Colonial Dutch Reformed Church: Problems and Proposals. In Patterns and Portraits, ed. Renee S. House and John W. Coakley, 16-32. Eerdmans, Grand Rapid: Women in the History of the Reformed Church of America.

30. Hall, David and Matthew Clarke. 1832. Legislative and Documentary History of the Bank of the United States. Washington: Gales and Seaton.

31. Hennessey v. Richardson Drug Co., 189 U.S. 25 (1903) 1903.

32. Jakobson, Roman. 2000 [1959]. On Linguistic Aspects of Translation. In A Translation Studies Reader, ed. Lawrence Venuti, 113-117. London: Routledge.

33. Jensen, Merrill (ed.). 1976. The Documentary History of the Ratification of the Constitution. Madison: State Historical Society of Wisconsin.

34. Kesavan, Vasan, and Michael Stokes Paulsen. 2003. The Interpretive Force of the Constitution's Secret Drafting History. Georgetown Law Journal 91: 1113-1214.

35. Klarman, Michael. 2016. The Framers' Coup. The Making of the United States Constitution. New York: Oxford University Press.

36. Kruenitz, Johann Georg. 1773-1858. Oeconomische Encyclopädie oder allgemeines System der Land-, Haus- und Staats-Wirthschaft: in alphabetischer Ordnung. Berlin: Pauli.

37. Lessig, Lawrence. 1993. Fidelity in Translation. Texas Law Review 71 (6): 1165-1268.

38. Maggs, Gregory. 2014. A Concise Guide to Using Dictionaries from the Founding Era to Determine the Original Meaning of the Constitution. George Washington Law Review 82: 358-393.

39. Maier, Pauline. 2010. Ratification: The People Debate the Constitution. New York: Simon and Schuster.

40. Manning, John F. 1989. Textualism and the Role of the Federalist in Constitutional Adjudication. George Washington Law Review 22 (5/6): 1337-1366.

41. McCulloch v. Maryland, 17 U.S. 316 (1819). 1819. Accessed.

42. Mulligan, Christina, Michael Douma, Hans Lind, and Brian Quinn. 2016. Founding-Era Translations of the US Constitution. Constitutional Commentary 31: 1-53.

43. Nat'1 Labor Rel. Bd. v. Noel Canning, 573 U.S. 513 (2014) 2014.

44. Natelson, Robert G. 2010. The Legal Origins of the Necessary and Proper Clause. In The Origins of the Necessary and Proper Clause, ed. Gary Lawson, Geoffrey Miller, Robert Natelson, and Guy Seidman, 52-83. New York: Cambridge UP.

45. Neusner, Jacob. 1986. Translation and Paraphrase: The Differences and Why They Matter. Hebrew Studies 27: 26-37.

46. New York Times. 2012. Bucking Senate, Obama Appoints Consumer Chief. Jan. 4, 2012. https:// www.nytimes.com/2012/01/05/us/politics/richard-cordray-named-consumer-chief-in-recess-appoi ntment.html. Accessed 4 March 2020.

47. Noel Canning v. Nat'l Labor Rel. Bd., 705 F.3d 490 (D.C. Cir. 2013$) 2013$.

48. Paulsen, Michael. 2007. Debate on the Original Meaning of the Commerce, Spending, and Necessary and Proper Clauses. In Originalism: A Quarter-Century of Debate, ed. Steven Calabresi, 253286. Washington, DC: Regnery Publishing.

49. Perea, Juan. 1992. Demography and Distrust: An Essay on American Languages, Cultural Pluralism, and Official English. Minnesota Law Review 77: 269-373.

50. Ritter, Johann, and Carl Kessler (eds.). 1907. Geseze der Republik Pennsylvanien, in übersezten Auszügen. Enthaltend die brauchbaren öffentlichen Geseze bis zu dem Jahr 1805, einschließlich: So wie auch die Regierungs-Verfassungen der Vereinigten Staaten und von Pennsylvanien, hrg. under Authorität eines Gesezes der General-Assembly, paßirt im April, 1805. Readingessler: Karl.

51. Robinson, Douglas (ed.). 2002. Western Translation Theory from Herodotus to Nietzsche. Manchester: St. Jerome.

52. Röding, Carl (ed.). 1832. America im Jahre 1831. Hamburg: Hoffmann und Campe.

53. Rogler, John Bartholomew. 1763. A Dictionary. English, German and French. Leipzig: John Frederick Gleditsch. 
54. Seidensticker, Oswald. 1889. Frederick Augustus Conrad Muhlenberg, Speaker of the House of Representatives, in the First Congress, 1789. Pennsylvania Magazine of History and Biography 1: 184-206.

55. Smith, Douglas. 1997. The Privileges and Immunities Clause of Article IV, Section 2: Precursor to Section 1 on the Fourteenth Amendment. San Diego Law Review 34: 809-920.

56. Solan, Lawrence. 2009. The Interpretation of Multilingual Statutes by the European Court of Justice. Brooklyn Journal of International Law 34 (2): 277-301.

57. Solan, Lawrence. 2014. Multilingualism and Morality in Statutory Interpretation. Language and Law 1 (1): 5-21.

58. Solum, Lawrence. 2008. Originalism and the Natural Born Citizen Clause. Michigan Law Review 107 (3): 593-601.

59. Solum, Lawrence. 2011. What is Originalism. In Constitutional Originalism: A Debate, ed. Robert Bennett and Lawrence Solum. London: Cornell University Press.

60. Spiro, Peter. 2008. McCain's Citizenship and Constitutional Method. Michigan Law Review 107: $42-48$.

61. Steiner, George. 2000 [1975]. The Hermeneutic Motion. In The Translation Studies Reader, ed. Lawrence Venuti, 186-191. London: Routledge.

62. Tress, Will. 2009. Unintended Collateral Consequences: Defining Felony in the Early American Republic. Cleveland State Law Review 57: 461-491.

63. Tribe, Laurence, and Theodore Olson. 2008. Presidents and Citizenship. Opinion letter, March 19, 2008. Journal of Law 2: 509-512.

64. United States v. Morrison, 529 U.S. 598 (2000) 2000.

65. Van Dale, Johan Hendrik. n.d. Groot woordenboek van de Nederlandse taal. https://www.vandale.nl. Accessed 4 March 2020.

66. Van Der Sijs, Nicoline. 2009. Cookies, Coleslaw, and Stoops: The Influence of Dutch on the North American Languages. Amsterdam: Amsterdam University Press.

67. Venuti, Lawrence. 2000. The Translation Studies Reader. London: Routledge.

68. Wagner, Adolf. 1818. Dr. Benjamin Franklin's Leben. Erster Band. Weimar: Verlag des LandesIndustrie Comptoirs.

69. Whittington, Keith. 2004. The New Originalism. Georgetown Journal of Law and Public Policy 22: 599-613.

70. 1768. The English Cellarius Or A Dictionary English And German. Hildeburghausen: Johann Gottfried Hanisch.

71. 1787 (presumed). Verfahren der Vereinigten Convention gehalten zu Philadelphia, In dem Jahr1787, Und dem Zwölften Jahr der Americanischen Unabhängigkeit. Auf Verordnung der General Assembly von Pennsylvanien aus dem Englischen übersetzt. Germantaun: Michael Billmeyer.

72. 1788. De Constitutie, eenpariglyk geaccordeerd by de Algemeene Conventie, gehouden in de Stad von Philadelphia, in 't Jaar 1787: en gesubmitteerd aan het Volk der Vereenigde Staaten d NoordAmerika, Vertaald door Lambertus de Ronde, Gedruckt by Order van de Federal Committee, in de Stad van Albany: Charles $R$. Webster.

73. 1823. Corfield v. Coryell, 6 F. Cas. 546 (C.C.E.D. Pa. 1823).

Publisher's Note Springer Nature remains neutral with regard to jurisdictional claims in published maps and institutional affiliations. 